УДК 631.576:631.55:338.439.63

(C) 2012

Кондратенко П. В., доктор сільськогосподарських наук, академік, Шевчук Л. М., кандидат сільськогосподарських наук Інститут садівництва (IC) НААН України

\title{
ПЕРСПЕКТИВИ ЗАБЕЗПЕЧЕННЯ ПРОДУКТАМИ САДІВНИЦТВА НАСЕЛЕННЯ УКРАЇНИ
}

\section{Рецензент - доктор сільськогосподарських наук І. К. Омельченко}

Розглянуто проблему збалансованого харчування украӥниів, зокрема, забезпечення людського організму важливими харчовими речовинами, що містяться у плодах та ягодах. На базі Галузевої програми розвитку садівництва Украӥни до 2017 року, запланованого валового збору плодових культур, проведено його розподіл по використанню, тобто споживання плодів у свіжому й переробленому вигляді. Виходячи зі строків достигання та можливих термінів зберігання плодово-ягідної продукиії, розраховано помісячні норми ї̈ споживання одиницею населення, а також обраховано надходження в людський організм зі згаданою продукиією вітаміну $C$.

Ключові слова: плоди, харчова цінність, валовий збір, норми спожсивання, вітамін $C$.

Постановка проблеми. Швидкі темпи розвитку суспільства досить часто негативно впливають на збалансованість харчування населення за основними складовими показниками (білки, жири, вуглеводи, вітаміни). Нестача в раціонах харчування багатьох людей необхідних для нормального функціонування поживних речовин $\epsilon$ надзвичайно актуальною як у розвинутих країнах, так і у країнах, що розвиваються, у тому числі й в Україні.

За оцінками фахівців, харчування українців розбалансоване за вмістом ретинолу (72\%), аскорбінової кислоти (34 \%), кальциферолу (62 \%), фолієвої кислоти (14\%), тощо. Раціон харчування дітей неповноцінний за кількістю складних вуглеводів, мікро- та макроелементів, - їх надходить в організм значно менше рекомендованих норм фізіологічних потреб в основних продуктах харчування [2]. Значна частина згаданих вище поживних речовин у людський організм поступає 3 продуктами рослинного походження, а саме овочами та фруктами.

Аналіз останніх досліджень і публікацій, у яких започатковано розв'язання проблеми. Постачальниками біологічно активних речовин, вітамінів, мікро- і макроелементів $є$ плоди та ягоди. За даними Л. В. Метлицкого, вітамін С у великій кількості міститься у зелених плодах грецьких горіхів $(500$ мг/100 г), вітамін В - у ягодах суниці (16 мкг/100 г), вітамін Р (70 мг/100 г) є у плодах чорної смородини, каротиноїди (близько 40 мг/100 г) - в обліписі. Стосовно ж мінеральних речовин, то найбільше Са і P (37 та 30 мг/100 г відповідно) 3 плодових культур містять вишні, a Fe [2, 3] - груші [2]. Цінність традиційних культур, які вирощуються в Україні, полягає ще й у тому, що вони накопичують глюкозу, сахарозу, протопектин, водорозчинний пектин, органічні (яблучну, лимонну, щавлеву, янтарну та інші) кислоти, фенольні сполуки і ферменти. За даними Інституту садівництва НААН, вміст цукрів у плодах яблуні коливається від 7,0 до 18,0 \%, груші - від 5,0 до $10,0 \%$. Найвищий вміст пектинів із-поміж зерняткових культур мають яблука, - його кількість у них варіює в межах від 0,55 до 1,35\%. Вітаміном С плоди зерняткових культур небагаті, його вміст знаходиться в межах 4-6 у плодах груші та 8-12 мг/100 г сирої маси - в яблуках. Із кісточкових культур найбільше аскорбінової кислоти містять плоди аличі (від 8 до 23 мг на 100 г), а найменше - персика (від 4 до 8 мг/100 г сирої маси).

Плоди ягідних (як ніяких інших традиційних культур) наділені скарбницею необхідних людському організму харчових речовин, зокрема біологічно активних. Найбільшу кількість вітаміну С (від 43 до 300 мг/100 г сирої маси) спроможні накопичувати плоди чорної смородини, від 25 до 78 - порічок, від 20 до 93 - суниці, від 14 до 48 - малини і від 16 до 35 - агрусу.

Оскільки аскорбінова кислота і рутин накопичуються у плодах у сенергізмі, то кількість останнього вітаміну прямопропорційно залежить від вмісту першого. Кількісний та якісний вміст органічних сполук у плодах і ягодах значною мірою залежить від генетичних особливостей сорту, кліматичних умов регіону та погодних року вирощування, внесення добрив, способу утримання міжрядь у насадженнях, схем посадки, способів формування дерев й ін.

Метою і завданням досліджень, що викону- 
валися в Інституті садівництва НААН, було визначення кількості аскорбінової кислоти, яка надходитиме до організму людини разом із плодами. Дані дослідження базуються на Галузевій програмі розвитку садівництва до 2017 року, яка наразі розробляється й має бути основним орієнтуючим документом у розвитку садівничої галузі в Україні.

Матеріали і методи досліджень. Протягом 1994-2011 pр. вивчали вміст аскорбінової кислоти у плодах традиційних плодових культур (яблуні, груші, вишні, черешні, сливи, абрикоса, малини, суниці, чорної смородини та ін.). Плоди для досліджень відбирали в насадженнях, розміщених у різних грунтово-кліматичних регіонах України. Відбір зразків та лабораторні дослідження проводили згідно 3 «Методичними рекомендаціями проведення досліджень по питаннях зберігання та переробки» [3] та «Методикою оцінки якості плодово-ягідної продукції» [4]. Математичну обробку результатів виконували шляхом регресивного аналізу за діючими методичними рекомендаціями з використанням персонального комп'ютера за відповідними програмами П. В. Кондратенка та М. О. Бублика [1]. Згідно з Галузевою програмою розвитку садівництва до 2017 року, за розрахунками економістів, валовий збір плодів у 2017 р. має становити 2578,9 млн тонн. Базуючись на цьому та беручи до увага строки достигання й потенціал лежкості плодів, нами був запропонований розподіл споживання плодової продукції на одиницю населення по місяцях. Біохімічні дослідження з вивчення вмісту вітаміну С в плодах, вирощених у різних регіонах України, та потенціалу різних сортів плодових культур щодо його збереження під час тривалого зберігання дозволило нам зробити розрахунки можливого надходження до людського організму аскорбінової кислоти разом із продуктами плодівництва.

Результати досліджень. Згідно $з$ наказом Міністерства охорони здоров'я України про «Норми фізіологічних потреб населення України в основних харчових речовинах та енергіï», середній пересічний громадянин залежно від групи зайнятості повинен споживати в день продукти харчування, що містять 392-560 г вуглеводів, 37-40 г рослинних білків, 1000-1100 мкрг вітаміну $\mathrm{A}, 1,3-2,0$ мг вітамінів $\mathrm{B}_{1}, \mathrm{~B}_{2}, \mathrm{~B}_{6}, 70-80$ мг аскорбінової кислоти, а також повний комплекс мінеральних речовин (Ca, P, Fe та ін.). Більшість останніх у незначних кількостях містяться в плодах. Добова потреба дитячого організму у вітаміні С становить 45, а дорослого - 75 мг, рі- чна - 16 г 425 мг та 27 г 375 мг відповідно $[5,6]$. Виходячи 3 потреб людського організму у вітаміні C, добову норму можна забезпечити споживанням 25-45 г ягід чорної смородини, 100-120 - суниці, 200-350 - малини, 100-200 - порічок, а в вітаміні P - 15-20 - чорної смородини, 20-40суниці, 50-70 г - малини, 80-120 - агрусу.

Відповідно до програми розвитку садівництва, у 2017 році українці споживатимуть 1996,4 тис. т плодово-ягідної продукції у свіжому вигляді, тобто 45,4 кг на одиницю населення, 60,0 тис. т плодів та ягід, які зберігатимуться у замороженому стані, що становитиме 1,4 кг на кожного. Реалізація свіжих плодів і ягід за схемою «сад прилавок» становитиме 699,4 тис. т, тобто $27 \%$ від запланованого валового збору. 3 цього асортименту 256,4 тис. т - плоди зерняткових культур, 338,3 тис. - кісточкових, 104,7 тис. т - ягідних. Решта зібраного урожаю повинна розподілятися таким чином: 1297,0 тис. т (50,4 \%) від валового збору мають зберігатися протягом тривалого часу і реалізуватися в міру необхідності та закінчення терміну їх зберігання, а 582,6 тис. т $(22,6 \%)$ зібраного врожаю будуть відправлені на переробку (соки, наповнювачі для кондитерської, хлібопекарської та молочної галузей, заморозку та інші консерви, що потребує ринок) (табл. 1).

Отже, щодо плодів зерняткових культур у 2017 році пересічний українець споживатиме їх 33,2 кг. Влітку (зважаючи на те, що достигають плоди інших культур) споживання яблук та груш становитиме 1,5 кг на місяць, що відповідає 150 мг аскорбінової кислоти в інші сезони року; місячну норму споживання буде збільшено до 3,4 кг, відповідно, і надходження в людський організм вітаміну С зросте до 340 мг.

Враховуючи гіршу, в порівнянні із зернятковими плодами, лежкість кісточкових і ягідних культур, сезон їх споживання у свіжому вигляді 3 урахуванням терміну зберігання триває протягом чотирьох-шести місяців. Влітку, коли більшість плодів згаданих культур заповнюють споживчий кошик, надходження аскорбінової кислоти, згідно з розрахованими нормами споживання (табл. 2), становитиме (плоди кісточкові 1,5-2,1 кг) - 150-210, (ягідні 0,2-0,5 кг) - 140900 мг. В інші періоди року плоди кісточкових та ягідних культур є доступними для споживання лише після дефростації. Слід зауважити, що у розморожених плодах, залежно від культури та сорту, вміст аскорбінової кислоти зменшується на 25-80 \% у порівнянні зі свіжими, тому й надходження її споживачеві буде меншим. 


\section{1. Пропозиції щодо розподілу валового збору плодів за групами призначення на 2017 р.} (muc. m)

\begin{tabular}{|c|c|c|c|c|c|c|c|c|}
\hline \multirow{3}{*}{$\begin{array}{c}\text { Групи } \\
\text { культур, } \\
\text { культура }\end{array}$} & \multirow{3}{*}{$\begin{array}{c}\text { Запла- } \\
\text { нований } \\
\text { валовий } \\
\text { збір }\end{array}$} & \multirow{3}{*}{$\begin{array}{c}\text { Спожи- } \\
\text { вання у } \\
\text { свіжому } \\
\text { вигляді без } \\
\text { зберігання }\end{array}$} & \multirow{2}{*}{\multicolumn{2}{|c|}{$\begin{array}{c}\text { Зберігання у свіжому } \\
\text { вигляді }\end{array}$}} & \multirow{3}{*}{$\begin{array}{c}\text { Зберіган- } \\
\text { ня у за- } \\
\text { мороже- } \\
\text { ному } \\
\text { стані }\end{array}$} & \multicolumn{3}{|c|}{ Плоди для переробки } \\
\hline & & & & & & \multirow[b]{2}{*}{$\begin{array}{c}\text { соки } \\
\text { «рреш» }\end{array}$} & \multirow{2}{*}{$\begin{array}{c}\text { натуральні } \\
\text { соки, } \\
\text { соки- } \\
\text { концент- } \\
\text { рати } \\
\end{array}$} & \multirow{2}{*}{$\begin{array}{c}\text { наповню- } \\
\text { вачі, висо- } \\
\text { коцукрис- } \\
\text { ті консер- } \\
\text { ви, інше }\end{array}$} \\
\hline & & & $\begin{array}{c}\text { зберігання } \\
\text { в 3А }\end{array}$ & $\begin{array}{l}\text { зберігання } \\
\text { в РА, МА }\end{array}$ & & & & \\
\hline $\begin{array}{c}\text { Зернятко- } \\
\text { ві }\end{array}$ & 1831,7 & 256,4 & 287,8 & 915,0 & - & 9,5 & 271,3 & 91,7 \\
\hline $\begin{array}{l}\text { Кісточко- } \\
\text { ві }\end{array}$ & 596,5 & 338,3 & - & 91,1 & 47,9 & 1,2 & 29,6 & 88,4 \\
\hline $\begin{array}{c}\text { Ягідні } \\
\text { (кущові) }\end{array}$ & 72,5 & 50,7 & - & 1,5 & 5,8 & 0,15 & 3,6 & 10,8 \\
\hline Суниця & 78,2 & 54,0 & - & 1,6 & 6,3 & 0,8 & 3,9 & 11,6 \\
\hline \multirow{2}{*}{ Усього } & \multirow{2}{*}{2578,9} & \multirow{2}{*}{699,4} & \multirow{2}{*}{287,8} & PA 9150 & \multirow{2}{*}{60,0} & \multirow{2}{*}{11,7} & \multirow{2}{*}{308,4} & \multirow{2}{*}{202,5} \\
\hline & & & & MA 94,2 & & & & \\
\hline
\end{tabular}

\section{2. Споживання плодів та ягід по місяцях зzідно із запланованим на 2017 рік валовим збором} (кг на людину)

\begin{tabular}{|c|c|c|c|c|c|c|c|c|c|c|c|c|c|}
\hline \multirow{2}{*}{$\begin{array}{c}\text { Групи } \\
\text { плодово- } \\
\text { ягідної та } \\
\text { горіхо- } \\
\text { плідної } \\
\text { продукції }\end{array}$} & \multicolumn{13}{|c|}{ Норми споживання плодів та ягід по місяцях (кг) } \\
\hline & $\begin{array}{l}\text { 荵 } \\
\text { 离 } \\
\text { 总 }\end{array}$ & 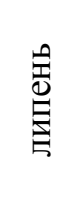 & $\begin{array}{l}\text { 覀 } \\
\stackrel{0}{0} \\
\stackrel{0}{0}\end{array}$ & 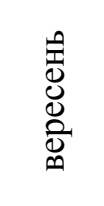 & 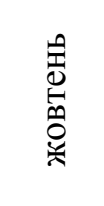 & 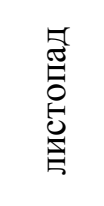 & 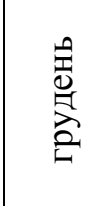 & 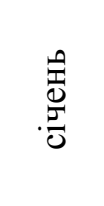 & 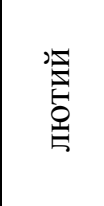 & 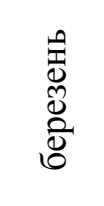 & 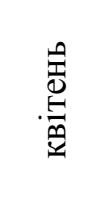 & $\begin{array}{l}\text { 怠 } \\
\text { 芯 } \\
\text { 芯 }\end{array}$ & $\begin{array}{l}0 \\
0 \\
0 \\
0 \\
\lambda\end{array}$ \\
\hline $\begin{array}{c}\text { Зерняткові } \\
\text { культури }\end{array}$ & 3,4 & 1,5 & 1,5 & 1,5 & 1,5 & 3,4 & 3,4 & 3,4 & 3,4 & 3,4 & 3,4 & 3,4 & 33,2 \\
\hline $\begin{array}{c}\text { Кісточкові } \\
\text { культур }\end{array}$ & 1,5 & 2,0 & 2,1 & 2,1 & 0,5 & 0,5 & 0,5 & 0,5 & 0,28 & 0,28 & 0,28 & 0,28 & 10,9 \\
\hline $\begin{array}{c}\text { Ягідні } \\
\text { кущові }\end{array}$ & 0,2 & 0,5 & 0,5 & 0,05 & 0,05 & 0,028 & 0,028 & 0,028 & 0,028 & 0,028 & 0,028 & 0,027 & 1,4 \\
\hline Суниця & 0,4 & 0,4 & 0,022 & 0,022 & 0,022 & 0,022 & 0,022 & 0,022 & 0,022 & 0,022 & 0,022 & 0,3 & 1,3 \\
\hline Усього & 5,5 & 4,4 & 4,1 & 3,7 & 2,1 & 3,9 & 4,0 & 4,0 & 3,7 & 3,7 & 3,7 & 4,0 & 46,8 \\
\hline
\end{tabular}

\section{3. Вміст вітаміну С у щомісячній нормі споживання плодово-ягідної продукцї̈ (мг)}

\begin{tabular}{|c|c|c|c|c|c|c|c|c|c|c|c|c|c|}
\hline \multirow{2}{*}{$\begin{array}{c}\text { Групи } \\
\text { плодово- } \\
\text { ягідної, } \\
\text { горіхо-- } \\
\text { плідної } \\
\text { продукції }\end{array}$} & \multicolumn{13}{|c|}{ Місяці } \\
\hline & $\begin{array}{l}\text { 志 } \\
\text { 岕 } \\
\text { 岕 }\end{array}$ & $\begin{array}{l}\text { 咅 } \\
\stackrel{\Xi}{E}\end{array}$ & $\begin{array}{l}\text { 离 } \\
\text { : } \\
\text { 잉 }\end{array}$ & 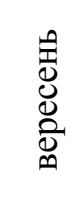 & 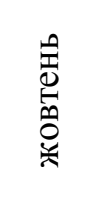 & 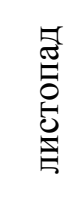 & 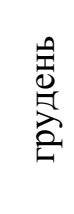 & $\begin{array}{l}\stackrel{0}{\mathbb{d}} \\
. \frac{\vec{v}}{0}\end{array}$ & $\begin{array}{l}\text { 罳 } \\
\text { 号 }\end{array}$ & 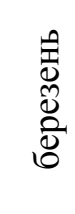 & 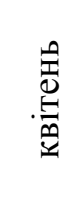 & $\begin{array}{l}\text { 胥 } \\
\text { 总 } \\
\stackrel{0}{0}\end{array}$ & $\begin{array}{l}0 \\
0 \\
0 \\
0 \\
0\end{array}$ \\
\hline Зерняткові & 340 & 150 & 150 & 150 & 150 & 340 & 340 & 340 & 340 & 340 & 340 & 340 & 3320 \\
\hline Кісточкові & 150 & 200 & 210 & 210 & 50 & 50 & 50 & 50 & 20 & 20 & 20 & 20 & 1050 \\
\hline $\begin{array}{c}\text { Ягідні } \\
\text { кущові }\end{array}$ & 140 & 900 & 900 & 80 & 80 & 20 & 20 & 20 & 20 & 20 & 20 & 20 & 2240 \\
\hline Суниця & 200 & 200 & 12 & 12 & 12 & 12 & 12 & 12 & 12 & 12 & 12 & 12 & 520 \\
\hline Усього & 830 & 1450 & 1272 & 452 & 292 & 422 & 422 & 422 & 392 & 392 & 392 & 392 & 7130 \\
\hline
\end{tabular}

Найбільшим воно буде 3 червня по серпень, що поденно становитиме від 48,3 до 26,7 мг, а найменшим у жовтні (292 мг із кількістю спожи- вання на день 9,7 мг). У решту місяців цей показник варіюватиме від 392 до 422 мг, тобто 13,1 i 14,1 мг щодня. За таких умов для збалансованос- 
ті раціону харчування населення України його необхідно доповнювати іншими С-вітамінними продуктами (табл. 3).

Висновки. Важливим фактором у забезпеченні населення країни продуктами харчування 3 високими поживними якостями, до групи яких належать плоди та ягоди, є виконання Галузевої програми розвитку садівництва України до

\section{БІБЛІОГРАФІЯ}

1. Кондратенко П. В., Бублик М. О. Методика проведення польових досліджень 3 плодовими культурами. - К. : Аграрна наука, 1996. - 95 с.

2. Концепція державної науково-технічної програми «Біофортифікація та функціональні продукти на основі рослинної сировини на 20122016 роки». - К., 2011. - С. 10.

3. Методика оцінки якості плодово-ягідної продукції. - К.: СПД «Житєлев С. І.». - 2008. - 79 с.

4. Методичні рекомендації проведення досліджень по питаннях зберігання та переробки. -
2017 року. Вона передбачає збільшення обсягів ïх виробництва, поліпшення якості та конкурентоспроможності на внутрішньому й зовнішньому ринках. Важливою запорукою виконання даної програми є підтримка держави у плані надання пільгових кредитів виробникам продукції на закладання плодово-ягідних насаджень, побудову плодосховищ та логістичних центрів.

К. : Аграрна наука, 1996. - 95 с.

5. Метлиикий Л. В. Основы биохимии плодов и овощей. - М.: Эконом. - 1976. - 347 с.

6. Наказ Мінстерства охорони здоров'я України №272 від 18.11.1999 «Про затвердження норм фізіологічних потреб населення України в основних харчових речовинах та енергіï».

7. Смірнова І. П., Давиденко Н. В., Горбась I. М. [ma iн.]. Принципи здорового харчування. Посібник для поліпшення якості роботи. - К., 2001. - C. 27. 